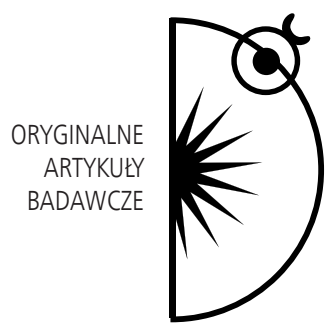

Agnieszka Iłendo-Milewska

Anna Wojtach

\title{
Jakość funkcjonowania uczniów w środowisku szkolnym - poczucie bezpieczeństwa w percepcji uczniów
}

DOI: http://dx.doi.org/10.12775/PBE.2013.018

\section{Wprowadzenie}

Analizy w obszarze jakości funkcjonowania współczesnej szkoły w Polsce wskazują na występujące w różnych dziedzinach jej życia zjawiska sprzeczne z powszechnie przyjętymi standardami, wartościami i oczekiwaniami społecznymi. Stwierdza się ponadto, że nie ma takiego obszaru funkcjonowania szkoły, w którym nie występowałyby problemy (Kwieciński, 1992). Najczęściej wymieniane pozostają w zakresie funkcjonowania członków społeczności szkolnej: nieakceptowane zachowania uczniów (agresja i przemoc, kradzieże, zażywanie narkotyków, picie alkoholu itp.), niepożądane zachowania nauczycieli, w tym przede wszystkim stosowanie przez nich przymusu, wymagania stawiane przez szkołę (w tym nadmierne obciążenie obowiązkami szkolnymi), lęk przed szkołą (lęk przed niepowodzeniem szkolnym, ekspozycją społeczną, przed nauczycielem i przed rywalizacją), nieprzydatność wiedzy szkolnej (Świątkiewicz, 2002). Bezpieczeństwo w szkole to jeden z głównych jej problemów. Co robić, by nie dopuścić do pojawienia się potencjalnie groźnych sytuacji, jak je rozwiązywać i jak im przeciwdziałać? 
Zapewnienie zdrowia i bezpieczeństwa dzieciom i młodzieży stanowi podstawowe zadanie, przed którym stają nauczyciele i rodzice (Klus-Stańska, Nowicka, 1999). Bezpieczeństwo dzieci i młodzieży musi być traktowane jako niepodważalna, fundamentalna reguła funkcjonowania szkoły i powinno być zagwarantowane każdemu młodemu człowiekowi, który w niej przebywa (Taraszkiewicz, Kordziński, 2009). Szkoła jako instytucja powinna modelowo dbać o jakość swoich wysiłków na rzecz bezpieczeństwa: biologicznego i fizycznego, ale też psychicznego i społecznego. Hasło „Szkoła wolna od przemocy" powinno określać misję każdej placówki oświatowej. Bezpieczna szkoła to miejsce, które zapewnia realizację podstawowych potrzeb ucznia. Stanowi przestrzeń, w której młody człowiek uczy się rozpoznawać swoje możliwości, planować swoje działania, uczy się współpracy i odpowiedzialności (Taraszkiewicz, Kordziński 2009).

\section{Rozważania teoretyczne}

Środowisko szkolne to wszystkie czynniki instytucjonalne, personalne i dydaktyczne, które występują w szkole. Na obraz środowiska szkolnego uczniów składa się charakterystyka osoby i zachowania nauczyciela, autoprezentacja jako identyfikacja ze środowiskiem szkolnym oraz charakterystyka otoczenia i stopnia identyfikacji z nim. Istnienie i jakość relacji ucznia z nauczycielami, a także identyfikacja z otoczeniem są wskaźnikami lepszego poznania funkcjonowania uczniów w środowisku szkolnym, dostarcza również informacji o poziomie ich dysfunkcjonalności (Gryniuk, Tuszyńska-Bogucka, 2004). Jednym z istotnych obszarów środowiska szkolnego jest podtrzymywanie i doskonalenie systemu, obejmujące formalne uporządkowanie środowiska szkolnego, jasność obowiązujących zasad oraz współdziałanie w ich przestrzeganiu i wzmacnianiu (Moos, 1979, s. 81-96).

Pojęcie funkcjonowanie określa rodzaj działania człowieka i dotyczy realizacji zadań w dziedzinie pełnionych ról społecznych (Mydlak, 1993), jakość funkcjonowania uczniów w środowisku szkolnym zależy od wspierania ich rozwoju lub od blokowania ich rozwojowych potencjałów. Za podstawę zmian w rozwoju dorastającej młodzieży, zgodnie z psychologią humanistyczną, przyjmuje się ich zdolność do rozwoju, uczenia się i podejmowania decyzji w oparciu o własne potrzeby i doświadczenia (Rogers, 1991). Młodzież ma potencjalne zdolności zdrowego i twórczego rozwoju, a zablokowanie możliwości rozwojowych związanych np. z ograniczającymi wpływami oddziaływań rodziców bądź szkoły (Hall, Lindzey, 2002) staje się przyczyną dysfunkcji. Rozwój 
przebiega w pewnych warunkach, które go ułatwiają lub utrudniają. Wyróżnia się następujące aspekty sytuacji szkolnej: subiektywną ocenę adaptacji do otaczającego ucznia środowiska szkolnego, jakość relacji rówieśniczych oraz jakość relacji z nauczycielami (Gryniuk, Tuszyńska-Bogucka, 2004).

Psychologia humanistyczna definiuje adaptację jako element procesu samorealizacji, w którym człowiek zaspokaja swoje potrzeby i odnajduje własne miejsce w otaczającej rzeczywistości. Podstawowymi czynnikami w procesie adaptacji, dzięki którym osoba podejmuje próby pokonywania trudności, własnych ograniczeń, napięć i realizowania swoich potencjałów, są: samoświadomość, indywidualna twórczość oraz otwartość na siebie i świat (Maslow, 1986, 1990; Rogers, 1991). Proces adaptacji nastolatka do środowiska szkolnego może przebiegać prawidłowo lub dysfunkcjonalnie, co manifestuje się w formie zachowań opracowanych przez Nowaka (1988) na podstawie klasyfikacji według typologii Mertona.

Do czynników powiązanych ze środowiskiem szkolnym należą też: ograniczona ilość i/lub jakość informacji dotyczących określonej sytuacji, zagrożenia związane z naruszeniem wymagań sytuacji, ograniczenia $\mathrm{w}$ gratyfikacjach związanych z procesem adaptacji.

Adaptację do środowiska szkolnego i bezpieczne w nim funkcjonowanie umożliwia młodemu człowiekowi stworzenie warunków sprzyjających wszechstronnemu rozwojowi, rozwijanie samoświadomości, twórczości i otwartości (Porzak, 1994).

Wychowawca, realizując proces wychowawczy oparty na podmiotowym traktowaniu ucznia, korzystając ze swoich cech i umiejętności, nie zmusza dziecka do rozwoju i realizacji własnych celów wychowawczych (Maslow, 1986; Łobocki, 1994). Nauczyciel powinien umożliwiać uczniom odnoszenie sukcesów w bezpiecznym dla nim środowisku, podnosić ich poziom aspiracji, pozytywnych oczekiwań i dobrego samopoczucia oraz wiary we własne siły. Wychowawca, tworząc bezpieczny i przyjazny klimat oparty na zaufaniu, szacunku i akceptacji - stwarza warunki wspomagające rozwój młodzieży, sprzyjające nabywaniu przez nich cech osobowości, objętych danym wzorcem osoby w pełni funkcjonującej - zarówno w ujęciu Rogersa, jak i Maslowa (Brammer, 1984; Porzak, 1994; Łobocki, 1994).

Oczywiście, w większym stopniu za jakość tych kontaktów odpowiedzialny jest nauczyciel (Sitarczyk, 1999), bowiem to nauczyciel stwarza bezpieczne środowisko (Więckowski, 1995), w którym rodzi się autentyczne zainteresowanie nauką i satysfakcja z osiągnięć. Nauczyciel powinien dążyć do przeniesienia przymusu zewnętrznego na wewnętrzny, który będzie wynikać z aspiracji i po- 
trzeb dzieci, zaangażowania oraz poczucia wolności wyboru. $\mathrm{W}$ takim środowisku kształtuje się optymalny rozwój osobowy dziecka. Nauczyciel w szkole opartej na koncepcji psychologii humanistycznej jest nauczycielem wyzwalającym, a nie hamującym czy ograniczającym. Poczucie bezpieczeństwa uczniów w środowisku szkolnym wyzwala dążność do poznania swojego „ja”, ekspresję uczuć, samoakceptację, odpowiedzialność, wrażliwość i empatię, postawy akceptacji, a także poczucie humoru. Nauczyciel w szkole bezpiecznej dla ucznia ma ułatwiać uczenie się, wspomagać uczniów własną wiedzą i postawami, być otwartym na ucznia, jego potrzeby, oczekiwania, powinien też ulegać inspiracjom uczniów i modyfikować swe działania oraz zachowanie zgodnie z niektórymi oczekiwaniami uczniów. Powinien być elastyczny intelektualnie i metodycznie, ujawniać swe zaufanie do uczniów, w komunikacji z nimi posługiwać się dialogiem, by wspomagać ich potencjał twórczy i indywidualny rozwój (Dróżdż, 2001).

Zatem wśród czynników oddziaływania profilaktycznego szkoły ważna jest diagnoza relacji z nauczycielami oraz relacji rówieśniczych, a także diagnoza środowiska szkolnego. Poznanie sytuacji szkolnej uczniów jest bowiem istotne dla projektowania skutecznych oddziaływań wychowawczych i profilaktycznych w szkole. W niniejszym artykule zostanie przedstawiony tylko jeden aspekt funkcjonowania uczniów w środowisku szkolnym - poczucie bezpieczeństwa.

Jakość funkcjonowania uczniów w środowisku szkolnym zależy od wspierania ich rozwoju lub od blokowania ich rozwojowych potencjałów. Jednym z warunków zapewnienia poczucia bezpieczeństwa w szkole jest świadomość jednoznacznej przynależności do określonego środowiska i własnego w nim miejsca. Bezpieczeństwo zależy także od poczucia zdrowej więzi z grupą, adekwatnej samooceny oraz zdolności do stanowczej odmowy w sytuacji presji ze strony innych ludzi (Klus-Stańska, Nowicka, 1999). Szkoła jest miejscem kształtowania postaw, nawyków oraz stylu życia młodych ludzi. Spędzają oni w niej dużo czasu, dlatego ważne jest, aby było to otoczenie przyjazne, bezpieczne i zdrowe.

System normatywny jest rdzeniem każdej społeczności, także społeczności uczniowskiej. Jego jakość decyduje zatem o funkcjonowaniu w środowisku szkolnym nie tylko poszczególnych uczniów, ale także i innych podmiotów biorących udział w procesie edukacyjnym. Im silniejszy jest system normatywny, tym lepiej funkcjonuje cała placówka oświatowa, tj. sprawniej i efektywniej realizuje postawione przed sobą zadania. By można było mówić o silnym systemie normatywnym, powinny być spełnione następujące warunki: wyraźna 
kodyfikacja zasad oraz ich znajomości przez członków danej zbiorowości, skuteczne, tj. sprawnie działające sankcje (sankcje nie mogą być fikcją, ale efektywnym narzędziem nacisku skłaniającym do odpowiedniego zachowania), skrupulatne i konsekwentne wywiązywanie się odpowiedzialnych za stan porządku społecznego z powierzonych im zadań (Zemło, 2012).

\section{Metodologia badań własnych}

Niniejszy artykuł zawiera wyniki badań własnych przeprowadzonych w $\mathrm{Pu}-$ blicznym Gimnazjum w Białymstoku trzykrotnie, na przestrzeni kilku lat, tj. w 2000 r., 2002 r. i 2010 r., wśród uczniów klas pierwszych, drugich i trzecich publicznego gimnazjum. Kwestionariusz ankiety „Ja i moja szkoła” został przeprowadzony 9 i 13 czerwca 2000 r., kwestionariusz ankiety „Atmosfera w szkole" - na przełomie listopada i grudnia 2002 r., natomiast kwestionariusz ankiety „Diagnozowanie zachowań uczniów związanych z bezpieczeństwem” został przeprowadzony od lutego do marca $2010 \mathrm{r}$.

W prowadzonych badaniach szkoła została wybrana drogą losową, w badaniach wzięło udział 300 uczniów publicznego gimnazjum, którzy wypełnili kwestionariusz ankiety przy zachowaniu pełnej anonimowości i przy zapewnieniu, że uzyskane wyniki posłużą jedynie do celów badawczych. W badaniach własnych dobór próby był warstwowy: klasy pierwsze, drugie i trzecie.

Celem ogólnym badania było poznanie opinii uczniów na temat bezpieczeństwa w szkole, zdiagnozowanie sytuacji szkolnej oraz wypracowanie działań podnoszących bezpieczeństwo uczniów w środowisku szkolnym. Wymienione kwestionariusze ankiety stanowią opracowanie własne. Zawierają one pytania wspólne dotyczące m.in. szkolnego systemu normatywnego. Celem zdiagnozowania poczucia obecności regulacji stanowiących o normach życia w instytucji, jaką jest szkoła, zadano uczniom pytania, np. „Czy znasz zasady zachowania się w szkole?”, „Czy przestrzegane są w szkole zasady zachowania się uczniów?”, „Które z zasad obowiązujących w szkole uważasz za najważniejsze?”. Uczniowie mieli także możliwość wypowiedzenia się w kwestii „przyczyn/powodów łamania norm szkolnych, miejsc w szkole, gdzie czują się najbezpieczniej i najmniej bezpiecznie". Kwestionariusz ankiety zawierał także pytania dotyczące poczucia bezpieczeństwa uczniów, np. „Czy czujesz się w szkole bezpiecznie?”. Obliczeń statystycznych w programie SPSS Statistic 17 dokonano na podstawie przypisania w pytaniach zamkniętych wartości 1 dla opinii „tak”, 2 dla opinii „nie”, 3 dla opinii „nie wiem” bądź w innych pytaniach przez przypisanie kolejnym pytaniom kolejnych wartości od 1 aż do wartości 12. 
Akcent został położony na zbadanie jakości środowiska szkolnego oraz zidentyfikowanie czynników chroniących i czynników ryzyka, jakim podlega współczesna młodzież szkolna, by móc wskazać szczególnie te z nich, które pełnią destrukcyjną funkcję.

Wyniki badań pozwoliły na zidentyfikowanie i oszacowanie zagrożeń towarzyszących procesowi przemian zachodzących we współczesnej szkole. Nie dążono do formułowania sądów ogólnych o całej społeczności młodzieży szkolnej, jednak prezentowane wyniki wskazują na potrzebę pogłębionych analiz w tym zakresie.

\section{Prezentacja wyników badań własnych w obszarze poczucia bezpieczeństwa uczniów w szkole}

Istnienie i znajomość szkolnego systemu normatywnego jest podstawą kształtowania poczucia bezpieczeństwa uczniów w szkole. Analizując wnikliwie świadomość uczniów w zakresie istnienia reguł szkolnych, zadano uczniom gimnazjum pytanie: „Które z zasad obowiązujących w szkole uważasz za najważniejsze?". Dane dotyczące najważniejszych zasad obowiązujących w publicznym gimnazjum zestawiono w tabeli 1 .

Tabela 1. Najważniejsze zasady obowiązujące w szkole

\begin{tabular}{|l|c|c|}
\hline \multirow{2}{*}{$\begin{array}{c}\text { Które z zasad obowiązujących w szkole } \\
\text { uważasz za najważniejsze? }\end{array}$} & $\mathbf{N}=300$ & $\%$ \\
\cline { 2 - 3 } & 30 & 10 \\
\hline systematycznie i aktywnie uczestniczyć w zajęciach lekcyjnych & 42 & 14 \\
\hline właściwie zachowywać się w trakcie trwania lekcji & 23 & 7,6 \\
\hline właściwie zachowywać się na przerwach & 50 & 16,6 \\
\hline $\begin{array}{l}\text { przestrzegać zasad dobrego zachowania wobec nauczycieli } \\
\text { i pracowników gimnazjum }\end{array}$ & 50 & 16,6 \\
\hline przestrzegać zasad dobrego zachowania wobec kolegów & 30 & 10 \\
\hline nie używać i nie posiadać substancji psychoaktywnych & 34 & 11,3 \\
\hline dbać o swój wygląd estetyczny i higienę ciała & 19 & 6,3 \\
\hline przeciwdziałać niszczeniu mienia gimnazjum & 22 & 7,3 \\
\hline $\begin{array}{l}\text { przestrzegać zakazu używania telefonów komórkowych na } \\
\text { zajęciach lekcyjnych }\end{array}$ & 300 & 100 \\
\hline Razem & & \\
\hline
\end{tabular}

Źródło: badania własne, $2010 \mathrm{r}$. 
$\mathrm{Z}$ danych przedstawionych w tabeli wynika, że najważniejszą zasadą obowiązującą w szkole jest przestrzegać zasad dobrego zachowania wobec nauczycieli i pracowników gimnazjum oraz wobec kolegów (16,6\% dla każdej z odpowiedzi); następnie ważne dla uczniów jest właściwe zachowanie w trakcie trwania lekcji $(14 \%)$ oraz dbanie o swój wygląd estetyczny i higienę ciała $(11,3 \%)$. Natomiast najmniej ważne jest przestrzeganie zakazu używania telefonów komórkowych na zajęciach lekcyjnych $(7,3 \%)$ czy przeciwdziałanie niszczenia mienia gimnazjum $(6,3 \%)$.

Dane dotyczące znajomości zasad zachowania się, w opinii badanych uczniów, zawiera tabela 2 .

Tabela 2. Znajomość zasad zachowania się w szkole

\begin{tabular}{|l|c|c|c|c|c|c|c|c|}
\hline \multirow{2}{*}{$\begin{array}{c}\text { Czy znasz } \\
\text { zasady } \\
\text { zachowania się } \\
\text { w szkole? }\end{array}$} & \multicolumn{7}{|c|}{$\begin{array}{c}\text { Badania z roku } \\
2000\end{array}$} & \multicolumn{2}{|c|}{$\begin{array}{c}\text { Badania z roku } \\
2002\end{array}$} & \multicolumn{2}{c|}{$\begin{array}{c}\text { Badania z roku } \\
2010\end{array}$} & \multicolumn{2}{|c|}{ Razem } \\
\cline { 2 - 9 } & $\mathrm{N}=100$ & $\%$ & $\mathrm{~N}=100$ & $\%$ & $\mathrm{~N}=100$ & $\%$ & $\mathrm{~N}=300$ & $\%$ \\
\hline Tak & 59 & 59,0 & 61 & 61,0 & 63 & 63,0 & 183 & 61,0 \\
\hline Nie & 31 & 31,0 & 9 & 9,0 & 7 & 7,0 & 47 & 15,6 \\
\hline $\begin{array}{l}\text { znam tylko } \\
\text { niektóre zasady }\end{array}$ & 10 & 10,0 & 30 & 30,0 & 30 & 30,0 & 70 & 23,3 \\
\hline razem & 100 & 100,0 & 100 & 100,0 & 100 & 100,0 & 300 & 100,0 \\
\hline
\end{tabular}

Źródło: badania własne.

Dane zawarte w tabeli wskazują, że znacząca większość uczniów zna zasady zachowania się w szkole i utrzymuje się rosnąca tendencja na przestrzeni porównywanych lat. Jednak wydaje się, że aby zapewnić uczniom bezpieczeństwo w szkole wszyscy uczniowie powinni znać zasady w niej obowiązujące a 1/3 uczniów w 2000 r. udziela odpowiedzi, że nie zna zasad. Wzrasta jednak procent udzielonych odpowiedzi w obszarze „znam tylko niektóre zasady”.

Postanowiono poznać poczucie bezpieczeństwa uczniów, zadając młodzieży jednoznaczne pytanie „Czy czujesz się w szkole bezpiecznie?”. Wyniki badań porównawczych dotyczących poczucia bezpieczeństwa uczniów na terenie szkoły przedstawiono w tabeli 2 . 
Tabela 3. Poczucie bezpieczeństwa uczniów na terenie szkoły

\begin{tabular}{|l|c|c|c|c|c|c|c|c|}
\hline \multirow{2}{*}{$\begin{array}{c}\text { Czy czujesz } \\
\text { się w szkole } \\
\text { bezpiecznie? }\end{array}$} & \multicolumn{9}{|c|}{$\begin{array}{c}\text { Badania z roku } \\
2000\end{array}$} & \multicolumn{2}{|c|}{$\begin{array}{c}\text { Badania z roku } \\
2002\end{array}$} & $\begin{array}{c}\text { Badania z roku } \\
2010\end{array}$ & \multicolumn{2}{|c|}{ Razem } \\
\cline { 2 - 9 } & $\mathrm{N}=100$ & $\%$ & $\mathrm{~N}=100$ & $\%$ & $\mathrm{~N}=100$ & $\%$ & $\mathrm{~N}=300$ & $\%$ \\
\hline tak & 31 & 31,0 & 34 & 34,0 & 79 & 79,0 & 144 & 48,0 \\
\hline nie & 33 & 33,0 & 61 & 61,0 & 16 & 16,0 & 110 & 36,6 \\
\hline nie wiem & 36 & 36,0 & 5 & 5,0 & 5 & 5,0 & 46 & 15,3 \\
\hline razem & 100 & 100,0 & 100 & 100,0 & 100 & 100,0 & 300 & 100,0 \\
\hline
\end{tabular}

Źródło: badania własne.

Analiza danych zawartych w tabeli 3 wskazuje, iż 48,0\% ankietowanej młodzieży czuje się w szkole bezpiecznie, natomiast $36,6 \%$ nie czuje się w szkole bezpiecznie. $\mathrm{Z}$ analizy porównawczej danych w tabeli wynika, iż w $2000 \mathrm{r}$. większość badanych uczniów nie miała zdania na temat własnego poczucia bezpieczeństwa w szkole - 36\% zaznaczyło odpowiedź „nie wiem”, natomiast w 2002 r. większość uczniów (61\%) udzieliła odpowiedzi wskazującej, iż nie czują się w szkole bezpiecznie. Natomiast dane z badań przeprowadzonych w 2010 r. pozwalają przypuszczać, że uczniowie czują się w szkole bezpiecznie (79\% udzielonych odpowiedzi).

Zdaniem uczniów (badania w 2002 r.) dzieje się tak ponieważ ,jest wiele starszych osób, a ochroniarze nie zwracają na to uwagi”, „nie zawsze ochroniarze reagują, uczniowie są straszeni i bici przez starszych, jest dużo kpin, nietolerancji, arogancji”. Poza tym uczniowie zauważają, że „szkoła jest duża, wszyscy są anonimowi i ciężko jest »wyciągnąć« konsekwencje”. Brak bezpieczeństwa wynika zatem z przepełnienia w szkole, przemocy ze strony silniejszych, niereagowania na przemoc przez ochroniarzy (,zatrudniona ochrona nie monitoruje zachowań uczniów w szatni i na korytarzach").

Najważniejszą przyczyną niewłaściwego zachowania w szkole są, zdaniem uczniów ankietowanych w 2010 r., niewłaściwe relacje z rówieśnikami, które wynikają ,z chęci szpanowania przed kolegami i koleżankami, chęci bycia popularnym, fajnym, obawą przed odtrąceniem”. Wśród udzielonych odpowiedzi wskazujących na relacje z nauczycielami/sytuację szkolną uczniowie wymieniają: „brak reakcji ze strony niektórych nauczycieli”, „niewłaściwe relacje z nauczycielami”, „brak autorytetu nauczyciela”, ,złe oceny”, ,faworyzowanie kujonów”, „,brak dyscypliny na lekcji”, „krzyk nauczycieli”, „,niekonsekwen- 
cja nauczycieli”, „nudne lekcje”, „nieznajomość praw uczniów i obowiązków nauczycieli”. Natomiast przyczyny tkwiące w rodzinie to: „złe wychowanie”, „bezstresowe wychowanie”, „przemoc w domu”, „obojętność”, „brak rozmów z rodzicami”, „brak zainteresowania rodziców, brak opieki”. Uczniowie nie czują się bezpiecznie „w toaletach” oraz „w drodze do i ze szkoły”, a także „na korytarzu". W miejscach najbardziej niebezpiecznych uczniowie zetknęli się z „obrażaniem, poniżaniem, biciem i zastraszaniem”: „starsi: dokuczają, przezywają, poniżają, obrażają; zaczepiają pierwszaków bez powodu”.

W roli ofiary znalazło się 16,8\% ankietowanych uczniów - wówczas też $69,3 \%$ z nich miało doświadczenia wskazujące, że nikt nie udzielił im pomocy, natomiast 78,5\% twierdzi, że nie było ofiarą przemocy w szkole. Jednocześnie na pytanie, „Czy pomogłeś uczniowi, który był ofiarą przemocy?”, podobny procent uczniów udziela pomocy, co jej nie udziela (24,7\% uczniów udziela pomocy - 30,5\% uczniów nie udziela pomocy). Uczniowie w swojej klasie okazują względem siebie szacunek, zaufanie, życzliwość, jednak na terenie szkoły uczniowie nie okazują sobie szacunku, zaufania i życzliwości. Uczniowie poszczególnych klas są zgrani, jednak na terenie szkoły nie są względem siebie życzliwi i nie ufają sobie.

Dane dotyczące czynników zwiększających bezpieczeństwo uczniów w szkole zawiera tabela 4.

Tabela 4. Czynniki zwiększające bezpieczeństwo uczniów w szkole

\begin{tabular}{|l|c|c|}
\hline \multirow{2}{*}{$\begin{array}{c}\text { Zastosowanie którego z czynników } \\
\text { zwiększyłoby Twoje bezpieczeństwo w szkole? }\end{array}$} & \multicolumn{2}{c|}{ Badani uczniowie } \\
\cline { 2 - 3 } & $\mathbf{N}=300$ & $\%$ \\
\hline zwiększenie liczby dyżurów nauczycieli & 43 & 14,3 \\
\hline zainstalowanie kolejnych kamer & 47 & 15,6 \\
\hline dyżury uczniowskie, przy współpracy z Samorządem Uczniowskim & 19 & 6,3 \\
\hline zwiększenie liczby patroli policyjnych w rejonie szkoły & 36 & 12,0 \\
\hline reagować na przemoc w szkole & 68 & 22,6 \\
\hline konsekwentnie karać uczniów stosujących przemoc w szkole & 87 & 29,0 \\
\hline Razem & 300 & 100 \\
\hline
\end{tabular}

Źródło: badania własne $2010 \mathrm{r}$.

$\mathrm{Na}$ podstawie analizy danych zawartych w tabeli 3 można stwierdzić, że czynnikiem zwiększającym bezpieczeństwo uczniów jest „konsekwentne kara- 
nie uczniów stosujących przemoc w szkole" (29,0\% udzielonych odpowiedzi), następnie „reagowanie na przemoc w szkole” (22,6\% udzielonych odpowiedzi) oraz „zainstalowanie kolejnych kamer” (15,6\% udzielonych odpowiedzi). Najmniej uczniów $(6,3 \%)$ wskazało, że mogłyby być to „dyżury uczniowskie, przy współpracy z Samorządem Uczniowskim".

Uczniowie udzielali również innych odpowiedzi, wskazując m.in. na: „zainstalowanie kamer w łazienkach, tam gdzie są umywalki/zainstalowanie czujników na dym w łazienkach”; „większą ilość nauczycieli pilnujących łazienek, w których palą papierosy, konsekwentne karanie palaczy, a nie tylko zwracanie im uwagi”; „wprowadzenie atrakcji np. muzyki na przerwach”; „branie pod uwagę innych uczniów, a nie tylko ochranianie tego winnego, policję patrolującą osiedla, organizowanie spotkań z psychologiem szkolnym oddzielnie dla chłopców i dziewczyn”. Spośród badanych 54,9\% uczniów zna sposoby „rozładowania" emocji, natomiast 45,1\% uczniów takich sposobów nie zna.

Zdaniem uczniów, relacje między uczniami, nauczycielami i rodzicami w szkole można poprawić, „zmieniając nastawienie nauczycieli do uczniów, okazując szacunek, zwiększając wzajemne zaufanie, nie krytykując się wzajemnie, organizując ciekawsze lekcje, nie wyśmiewając się z siebie i nie wytykając błędów uczniom”. Można również „organizować wspólne imprezy, spotkania rodziców, uczniów i nauczycieli, tłumaczyć na lekcji, jeśli ktoś o to prosi”; „Zwiększyć ilość godzin wychowawczych i dodatkowych zajęć pozalekcyjnych". Ich zdaniem uczniów powinno się traktować jednakowo, częściej informować i nie zastraszać ocenami.

Większość uczniów sądzi, że szkoła nie wspomaga w procesie adaptacji uczniów klas pierwszych (39\%), 31\% uczniów natomiast sądzi, że wspomaga. Dzieje się tak, zdaniem uczniów, dlatego, że „każdy dba tylko o swoje interesy, starsi pogardzają młodszymi, są nietolerancyjni”.

\section{Dyskusja wyników badań własnych w świetle opublikowanych danych w obszarze poczucia bezpieczeństwa uczniów w szkole}

Podsumowując krótko wyniki badań własnych, podkreślić należy, iż większość uczniów jest świadomych, że w szkole należy przestrzegać obowiązujących zasad właściwego zachowania, a przekonanie o funkcjonowaniu reguł w gimnazjum deklaruje około $1 \frac{1}{3}$ gimnazjalistów. Wyraźna jest tendencja wskazująca na wzrastające poczucie bezpieczeństwa uczniów w szkole, a jego brak może wynikać - zdaniem badanych - z dużej liczby uczniów, przemocy ze strony silniejszych i niereagowania na przemoc ze strony ochrony szkoły. Uczniowie 
nie czują się bezpiecznie w toaletach, na korytarzu oraz w drodze do i ze szkoły. Za najważniejszą przyczynę nieodpowiedniego zachowania uczniowie uznają niewłaściwe relacje $\mathrm{z}$ rówieśnikami oraz trudności w kontaktach z nauczycielami. Uczniowie w swojej klasie okazują względem siebie szacunek i życzliwość, jednak na terenie szkoły nie są życzliwi wobec uczniów innych klas.

Badania własne dostarczają danych potwierdzających badania przeprowadzone w od października 2011 r. do marca 2012 r. w ramach projektu „Styl życia młodzieży Białegostoku" badania, realizowane przez Departament Spraw Społecznych Urzędu Miejskiego w Białymstoku za pośrednictwem Pracowni Badań, Analiz i Strategii Rozwoju Edukacji przy Centrum Kształcenia Ustawicznego w Białymstoku (Mantur, 2012). Ich celem było rozpoznanie środowiska szkolnego w percepcji uczniów białostockich szkół różnego typu. W badaniach realizowanych w projekcie „Styl życia młodzieży Białegostoku” wzięło udział 3404 uczniów. Dobór próby był wielostopniowy: typy szkół (publiczne i niepubliczne), rodzaje szkół (gimnazja, licea ogólnokształcące, szkoły zawodowe, technika), klasy (pierwsze, drugie i trzecie). W statystycznej analizie danych z projektu zastosowano test niezależności chi-kwadrat Pearsona do oceny związków pomiędzy cechami o charakterze jakościowym i porządkowym, obliczenia przeprowadzono w programie SPSS Statistic 19, a hipotezy weryfikowano na poziomie istotności 0,05 .

Celem zdiagnozowania poczucia obecności regulacji stanowiących o porządku życia w obrębie instytucji szkolnych w projekcie „Styl życia młodzieży Białegostoku” zadano uczniom pytanie: „Czy w szkole, do której uczęszczasz, są czytelne reguły mówiące, co wolno i czego nie wolno uczniowi?”. Uzyskano rozkład odpowiedzi przedstawiony na wykresie 1 .

Odpowiedzi potwierdzającej istnienie czytelnych reguł w środowisku szkolnym udzieliło $2 / 3$ uczniów, dla $1 / 3$ nie była to sprawa oczywista. Wśród tej drugiej grupy 7,8\% jednoznacznie odpowiedziało, że takich regulacji nie ma, natomiast 23,4\% wybrało kategorię „trudno powiedzieć”. Uzyskany rozkład wyników wskazuje, że przekonanie o funkcjonowaniu reguł w szkole nie jest powszechne, a należy pamiętać, że znajomość i dostosowywanie się do reguł panujących w społeczności, w jakiej dany system edukacyjny funkcjonuje, jest podstawową zasadą procesu wychowania (Zemło, 2012, s. 31). Istnieje zatem nieco paradoksalna sytuacja: środowisko, którego powołaniem jest kształtowanie świadomości zasad wśród swoich podopiecznych - a to najskuteczniej można czynić przez jednoznaczne wyznaczanie kodyfikacji regulujących i nieustanne odwoływanie się do nich, by te stały się naturalnym punktem odniesienia we wszelkich działaniach jednostek nie czyni tego w sposób skuteczny (Zemło, 
2012). Dostrzeganie czytelności reguł szkolnych różnicuje uczniów w sposób istotny statystycznie podwzględem rodzaju szkoły $\left(\mathrm{Chi}^{2}=43,230\right.$; Asym. Sig. $=0,000)$. Niżej zamieszczona tabela ilustruje uzyskane wyniki.

Wykres 1. Świadomość uczniów dotycząca istnienia czytelnych reguł postępowania w środowisku szkolnym

\section{Świadomość uczniów dotycząca istnienia czytelnych reguł postepowania $\mathrm{w}$ środowisku szkolnym}

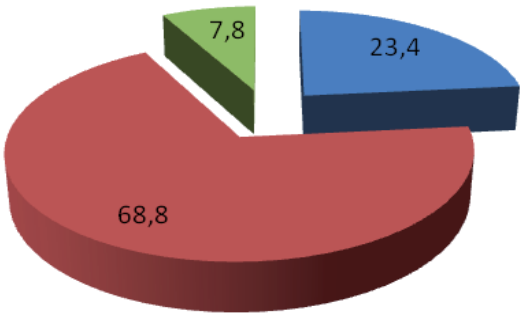

- Trudno powiedzieć

- Tak

nie

Źródło: Zemło, 2012.

Tabela 5. Rodzaj szkoły a świadomość istnienia czytelnych reguł szkolnych

\begin{tabular}{|l|c|c|c|c|c|}
\hline \multirow{2}{*}{$\begin{array}{c}\text { Czytelność reguł } \\
\text { szkolnych }\end{array}$} & \multicolumn{4}{|c|}{ Rodzaj szkoły } & \multirow{2}{*}{ Średnia } \\
\cline { 2 - 5 } & Gimnazjum & LO & \multicolumn{1}{c|}{ ZSZ } & Technikum & \\
\hline Tak & $66,7 \%$ & $68,0 \%$ & $69,5 \%$ & $72,5 \%$ & $68,8 \%$ \\
\hline Nie & $8,6 \%$ & $5,7 \%$ & $14,3 \%$ & $7,9 \%$ & $7,8 \%$ \\
\hline Trudno powiedzieć & $24,7 \%$ & $26,3 \%$ & $16,2 \%$ & $19,6 \%$ & $23,4 \%$ \\
\hline Razem & $100,0 \%$ & $100,0 \%$ & $100,0 \%$ & $100,0 \%$ & $100,0 \%$ \\
\hline
\end{tabular}

Źródło: Zemło, 2012, s. 31.

Biorąc pod uwagę odpowiedzi potwierdzające istnienie czytelnych reguł w środowisku szkolnym, najsłabiej wypada gimnazjum - 66,7\% wskazań, dalej plasują się kolejno: LO - 68,0\%, ZSZ - 69,5\%, technikum - 72,5\%. Analizując także odpowiedzi zdecydowanie zaprzeczające istnieniu reguł szkolnych, najwięcej wskazań zanotowano w ZSZ - 14,3\%, następnie w kolejności: gimna- 
zjum $-8,6 \%$, technikum $-7,9 \%$, LO $-5,7 \%$. Biorąc pod uwagę przedstawione dane, należy stwierdzić, że najsłabsza świadomość reguł szkolnych występuje w ZSZ oraz w gimnazjach, a najlepsza w technikach.

Nauczyciele wzmacniają system norm wówczas, gdy w sposób jasny i czytelny wskazują podopiecznym na reguły obowiązujące w środowisku szkolnym i czuwają nad ich przestrzeganiem. Przyczyniają się do osłabiania systemu, gdy nie wypełniają tych zadań lub wyraźnie je zaniedbują. By poznać jakość wychowawczej działalności nauczycieli w tym zakresie, czyli w obszarze jakości systemu normatywnego, w projekcie „Styl życia młodzieży Białegostoku”, zadano młodzieży pytanie: „Czy nauczyciele w Twoje szkole konsekwentnie czuwają nad przestrzeganiem istniejących reguł?”. Uzyskano rozkład wyników, który przedstawia wykres 2 .

Wykres 2. Konsekwentne egzekwowanie przez nauczycieli reguł zachowania odnoszących się do młodzieży szkolnej

\section{Konsekwentne egzekwowanie przez nauczycieli reguł zachowania odnoszących się do młodzieży szkolnej}

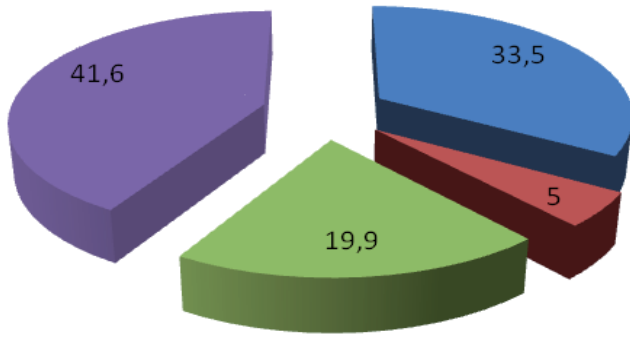

niektórzy

- Nie ma takich

Wszyscy

- Prawie wszyscy

Źródło: Zemło, 2012

Zdaniem 19,9\% badanej młodzieży „wszyscy nauczyciele konsekwentnie wykonują powierzone im zadania wychowawcze”; 41,6\% twierdzi, że „prawie wszyscy” to czynią, $33,5 \%$ wyraża opinie, że „tylko niektórzy wywiązują się z powierzonego im zadania”, a 5,0\% „w ogóle nie dostrzega ich zaangażowania" (Zemło, 2012, s.37).

Uzyskane wyniki badań własnych wraz z wynikami badań projektu „Styl życia młodzieży Białegostoku" nie wystawiają dobrego świadectwa środowi- 
sku nauczycieli i pozwalają stwierdzić, że wychowawcy nie prezentują jednolitego stanowiska, które byłoby jednoznacznie odbierane przez młodzież. Sprawia to, że we współczesnej szkole nie stwarza się uczniom warunków wychowawczych, które zapewniałyby skuteczne oddziaływanie pedagogiczne. Należy dążyć do konsekwentnego przestrzegania zasad zachowania obowiązujących w szkole i ze szczególną starannością dbać, by uczniowie nauczyli się odpowiedzialności za swoje niewłaściwe postępowanie i ponosili konsekwencje nieprzestrzegania szkolnych reguł. Jednoznacznie należy podkreślić, że konsekwentne wskazywanie zachowań pożądanych i tych dysfunkcyjnych, kształtowanie i wzmacnianie hierarchii priorytetów jest niezmiernie potrzebne. Kształtująca się w tym okresie osobowość adolescenta potrzebuje klarownych zasad, norm i reguł, w których bezpiecznie może funkcjonować. Bez jednoznacznego wspomagania ze strony wychowawców - nieukształtowany jeszcze człowiek jest pozostawiony samemu sobie i skazany na pomyłki, a skutki głęboko zapisują się w biografii i powracają przy okazji najróżniejszych sytuacji kryzysowych.

Podsumowując, można stwierdzić, że ukazane dane świadczą o słabej kondycji normatywnego sytemu szkolnego, który jest rdzeniem każdej społeczności, tzn. że rzutuje na jej funkcjonowanie w każdym możliwym wymiarze (Zemło, 2012).

$\mathrm{W}$ analizie należy uwzględnić jeszcze dwie zmienne niezależne: typ i rodzaj szkoły, z którymi w sposób istotny statystycznie koreluje konsekwentna, wychowawcza postawa nauczycieli (Zemło, 2012).

Tabela 6. Typ szkoły a konsekwentne działania wychowawcze nauczycieli

\begin{tabular}{|l|c|c|c|}
\hline \multirow{2}{*}{$\begin{array}{c}\text { Konsekwencja } \\
\text { w działaniach } \\
\text { nauczycieli }\end{array}$} & Szkoła publiczna & Szkoła niepubliczna & \multirow{2}{*}{ Średnia } \\
\cline { 2 - 3 } & $19,4 \%$ & $24,5 \%$ & $19,9 \%$ \\
\hline Wszyscy & $40,9 \%$ & $48,1 \%$ & $41,6 \%$ \\
\hline Prawie wszyscy & $34,8 \%$ & $22,3 \%$ & $33,5 \%$ \\
\hline Niektórzy & $5,0 \%$ & $5,2 \%$ & $5,0 \%$ \\
\hline Nie ma takich & $100,0 \%$ & $100,0 \%$ & $100,0 \%$ \\
\hline Razem & & & \\
\hline
\end{tabular}

Źródło: Zemło, 2012, s. 37. 
Stanowisko wskazujące, że „wszyscy nauczyciele konsekwentnie podejmują działania wychowawcze" wyrażał co piąty uczeń szkoły publicznej $(19,4 \%)$ i co czwarty uczeń szkoły niepublicznej (24,5\%). Łączna analiza kategorii »wszyscy« i »prawie wszyscy« czuwają nad przestrzeganiem przez młodzież reguł szkolnych" wskazuje na następujące wielkości: 60,3\% wskazań w szkołach publicznych i 72,6\% wskazań w szkołach niepublicznych. Na kategorię mówiącą o zaniedbywaniu przez edukatorów swoich obowiązków w obu typach placówek wskazał podobny odsetek uczniów. Reasumując, należy podkreślić, iż uczniowie niepublicznych szkół lepiej oceniają starania wychowawcze swoich opiekunów.

Opinie uczniów, na ten temat poddane analizie ze względu na rodzaj szkoły, prezentuje tabela 7. Dostrzeganie konsekwencji w działaniach nauczycieli różnicuje uczniów w sposób istotny statystycznie pod względem rodzaju szkoły $\left(\mathrm{Chi}^{2}=33,717\right.$; Asym. Sig. = 0,001) $($ Zemło, 2012).

Tabela 7. Rodzaj szkoły a konsekwentne działania wychowawcze nauczycieli

\begin{tabular}{|l|c|c|c|c|c|}
\hline \multirow{2}{*}{$\begin{array}{c}\text { Konsekwencja } \\
\text { w działaniach } \\
\text { nauczycieli }\end{array}$} & \multicolumn{4}{|c|}{ Rodzaj szkoły } & \multirow{2}{*}{ Średnia } \\
\cline { 2 - 5 } & Gimnazjum & LO & ZSZ & Technikum & \\
\hline Wszyscy & $21,1 \%$ & $17,9 \%$ & $31,4 \%$ & $19,0 \%$ & $19,9 \%$ \\
\hline Prawie wszyscy & $39,8 \%$ & $44,7 \%$ & $37,1 \%$ & $40,7 \%$ & $41,6 \%$ \\
\hline Niektórzy & $33,3 \%$ & $34,2 \%$ & $22,9 \%$ & $34,7 \%$ & $33,5 \%$ \\
\hline Nie ma takich & $5,8 \%$ & $3,1 \%$ & $8,6 \%$ & $5,5 \%$ & $5,0 \%$ \\
\hline Razem & $100,0 \%$ & $100,0 \%$ & $100,0 \%$ & $100,0 \%$ & $100,0 \%$ \\
\hline
\end{tabular}

Źródło: Zemło 2012, s. 37.

Uwzględniając kategorię mówiącą, że „wszyscy nauczyciele konsekwentnie podejmują działania wychowawcze", najlepszą opinie dla swoich wychowawców wystawili uczniowie z ZSZ - 31,4\%, o ponad 10 punktów procentowych wyprzedzając gimnazjum - 21,1\%, dalej uplasowało się technikum - 19,0\% i liceum - 17,9\%. Przy kategorii „prawie wszyscy” kolejność opowiadających się za nią uległa zmianie. Najwięcej wskazań uzyskała ona w LO - 44,7\%, a na kolejnych miejscach odpowiednio znalazły się: technikum - 40,7\%, gimnazjum - 39,7\%, ZSZ - 37,1\%. Najmniej wskazań mówiących o istnieniu nauczycieli zaniedbujących swoje obowiązki wychowawcze było w LO - 3,1\%, dalej $\mathrm{w}$ technikum $-5,5 \%$, gimnazjum - 5,8\%, ZSZ - 8,6\%" (Zemło, 2012, 
s. 37). Uwzględniając wszystkie udzielone odpowiedzi w tym zakresie, nasuwa się spostrzeżenie, że największe zaangażowanie wychowawców i ich konsekwentne działania notuje się w ZSZ.

Podsumowując, należy podkreślić, iż ważnym zadaniem nauczycieli jest ukształtowanie wśród uczniów poczucia odpowiedzialności za siebie i otoczenie, tak aby wspomagać utrzymanie jak najwyższego poziomu bezpieczeństwa w szkole. Wyniki badań z podziałem na rodzaj i typ szkoły wymagają kontynuowania ze względu na możliwość ukazania podobieństw, a także różnic. Na tej podstawie możliwe będzie określenie przyczyn i wskaźników różnicujących szkoły. Dyskusja prowadzona na tle dotychczasowej wiedzy w obszarze poczucia bezpieczeństwa uczniów w szkole wskazuje, iż jedną z najważniejszych strategii kształtowania bezpieczeństwa w szkole jest budowanie wspierających i opartych na wzajemnym szacunku relacji (Dotka, 2010). „Problem przemocy, który narasta w polskich szkołach przybiera charakter zbliżony do wojskowej »fali«. Chodzi tutaj o przemoc dzieci starszych i silniejszych wobec młodszych i słabszych. Głównymi ofiarami są uczniowie młodszych klas. Uczniowie starszych roczników wykorzystują młodszych kolegów do realizacji własnych celów" (Latecki, Krakowska, 2010, s. 207). Szkoła musi tworzyć własne programy prewencyjne, ale powinna też korzystać z dostępnych projektów pozaszkolnych oraz utrzymywać stały kontakt ze służbami i organizacjami zajmującymi się tym problemem. Nauczyciele i wychowawcy powinni dostosować programy profilaktyczne do realnych potrzeb swoich uczniów oraz realizować je na poziomie szkoły (np. akcje) i klas (np. zajęcia warsztatowe). Sami muszą stale podnosić swoje umiejętności w zakresie edukowania uczniów oraz podejmowania interwencji w sytuacjach zagrożenia. Jedną ze skutecznych metod zwiększania poczucia bezpieczeństwa uczniów jest informowanie ich o potencjalnych zagrożeniach oraz skłanianie do rozmów na ten temat (tu ważny jest otwarty i szczery kontakt wychowawców z klasą). W ten sposób podopieczni stają się bardziej świadomi i uważni na niepokojące sygnały, zachowania, nieznane osoby na terenie szkoły. Szkoła powinna systematycznie badać nie tylko stopień poczucia bezpieczeństwa uczniów, lecz także skuteczność stosowanych programów profilaktycznych. Regularne korekty działań zwiększają ich efektywność (Dotka, 2010). Uczniowie, wiedząc, że mają oparcie w szkole zarówno wśród innych uczniów, jak i nauczycieli, częściej mówią o problemach, proszą o pomoc, rzadziej naruszają zasady bezpieczeństwa i łatwiej internalizują obowiązujące normy.

„Zastanawiając się nad wyzwaniami i zagrożeniami, jakie stoją przed współczesną edukacją nie sposób nie zauważyć, iż jesteśmy świadkami pewnego 
novum w zakresie potrzeb wychowania, które zasadniczo powinno zmieniać charakter i kształt współczesnej edukacji w naszym kraju. [...] Ogromnej wagi nabiera szeroko rozumiana edukacja, realizowana co istotne, nie tylko przez szkołę, ale i przez innych uczestników życia społecznego - stowarzyszenia, instytucje, całe społeczeństwo" (Markocki, 2009, s. 171). W przypadku, gdy działania samej szkoły okazują się niewystarczające i nie można uzyskać zadowalających efektów, istnieje możliwość zwrócenia się o pomoc do poradni psychologiczno-pedagogicznej bądź specjalistycznej. Poradnia ma również możliwość prowadzenia różnorodnych form terapii oraz zajęć profilaktycznych (Tokarczyk, 1996). Ważnym obowiązkiem dyrektora jest współpraca z pozaszkolnymi podmiotami, które są odpowiedzialne za bezpieczeństwo i porządek, w szczególności z policją i strażą miejską. W ramach tej współpracy warto organizować spotkania pedagoga, nauczycieli, dyrektora szkoły z policjantami; wspólnie z policjantami przygotowywać spotkania dla młodzieży szkolnej; informować policję, gdy na terenie szkoły mają miejsce zdarzenia o znamionach demoralizacji; prosić o pomoc w rozwiązywaniu wyjątkowo trudnych problemów wychowawczych, a także wspólnie z policją brać udział w lokalnych programach profilaktycznych (Taraszkiewicz, Kordziński 2009).

Z przeprowadzonych badań własnych wynikają jednoznaczne wnioski:

1. Uczniowie są świadomi, że w szkole należy przestrzegać obowiązujących zasad właściwego zachowania. Należy jednak dążyć do konsekwentnego ich przestrzegania.

2. Wydaje się, że wyraźnemu umocowaniu w dokumentacji szkoły wymaga zasada odnosząca się do używania telefonów komórkowych podczas lekcji oraz podczas przerw, co łączy się także z potrzebą czy wręcz koniecznością konsekwentnego jej przestrzegania.

3. Należy poprawić relacje uczniów z rówieśnikami, wzmacniając ich pewność w podejmowaniu decyzji, należy eliminować presję grupy, jednocześnie integrować zespół klasowy, stwarzając liczne sytuacje do podejmowania wspólnych działań i wzajemnej pomocy. Niewłaściwe relacje z rówieśnikami są - zdaniem uczniów - najważniejszą przyczyną nieodpowiedniego zachowania w szkole.

4. Badania własne prowadzone w 2000 r., 2002 r. oraz 2010 r. wskazują, iż wzrasta bezpieczeństwo uczniów na terenie szkoły.

5. Należy podjąć działania zwiększające bezpieczeństwo uczniów w toaletach, zdaniem uczniów należy: „konsekwentnie karać palaczy, a nie tylko zwracać uwagę” czy „Zwiększyć ilość nauczycieli pilnujących łazienek, w których palą papierosy". 
6. Należy uświadamiać uczniów, że obrażanie, poniżanie są formą przemocy psychicznej, której konsekwencje są bardzo niebezpieczne. Należy podjąć działania profilaktyczne z młodzieżą starszych klas, mające na celu uświadomienie potrzeby pomocy uczniom z klas młodszych; istotne są także działania integracyjne uczniów całej społeczności szkolnej. Należy pracować nad „zgraniem” uczniów całej szkoły.

7. Należy uświadamiać uczniów o konieczności udzielania pomocy koledze/koleżance w sytuacji trudnej i uwrażliwiać uczniów na potrzeby drugiego człowieka. Powinno się uczyć szacunku do drugiego człowieka.

8. Podczas zajęć wychowawczych należy przeprowadzać lekcje na temat konstruktywnych sposobów „rozładowania” złości.

9. Należy dążyć do zmiany sytuacji, tak by wyeliminować sytuacje poniżania ucznia przez nauczyciela.

Pamiętać należy, że podmioty odpowiedzialne za zapewnienie niezbędnych warunków bezpieczeństwa w szkole to nie tylko nauczyciele i wychowawcy, ale także: dyrektor szkoły, specjalista do spraw BHP, pedagog/ /psycholog, rada rodziców i pielęgniarka szkolna (Taraszkiewicz, Kordziński 2009).

W realizacji zamierzonych celów niewątpliwie najistotniejszym zadaniem szkoły będzie stworzenie takiego środowiska szkolnego, by charakteryzowała go atmosfera ciepła, życzliwości, zrozumienia i tolerancji. Dzięki temu szkoła stanie się jeszcze bardziej przyjazna uczniowi, będzie miejscem, w którym młodzież poczuje się bezpiecznie, a co się z tym wiąże, będzie chętniej do niej uczęszczała i coraz aktywniej uczestniczyła w jej życiu (Grodowska, Kowalska, 2003). Wychowawcą, który zdawał sobie sprawę ze znaczenia atmosfery panującej $\mathrm{w}$ klasie oraz potrafił ją tworzyć tak dobrze, iż osiągnął w tym względzie światowy rozgłos, był Rogers. Jego zdaniem nie powinno się wpływać na drugą osobę, zalecając jej zmianę zachowania, należy ułatwiać podjęcie tej decyzji, a dobry nauczyciel rozumie różnicę między zalecaniem zmian a ich ułatwianiem. Ułatwianie zmian polega na tworzeniu szczególnej atmosfery psychologicznej (klimatu psychologicznego), która zaczyna się kształtować, gdy w postawach nauczyciela dominują: osobista autentyczność, empatyczne rozumienie uczuć ucznia i ich znaczenia, ciepło, a także bezwarunkowa akceptacja. Wymienione cechy, przejawiane początkowo przez nauczyciela, stopniowo są przejmowane przez uczniów. W warunkach tak rozumianej atmosfery psychologicznej uczniowi łatwiej jest podjąć decyzję o zmianie swego zachowania (Danilewska, 2002). 
W środowisku szkolnym sprzyjającym właściwym zachowaniom uczniów nauczyciel dzieli się odpowiedzialnością za proces edukacji, wdraża ucznia i siebie do samodyscypliny, samoanalizy i samooceny (Tchorzewski, 1994).

Psychologia humanistyczna wskazuje na jedną z najbardziej twórczych koncepcji oddziaływań dydaktyczno-wychowawczych, promującą rozwój nastolatka i zapobiegającą pojawianiu się patologii, jaką jest model PCA (Person Centered Approach) opracowany przez Rogersa (1983). Wydaje się, że jego podstawowe tezy zastosowane we współczesnej szkole mogą mieć znaczący wpływ na poprawę bezpieczeństwa uczniów:

1. Nauczyciel ma wystarczająco duże zaufanie do siebie i do uczniów, aby wierzyć, że inni, tak jak on sam, potrafią myśleć o sobie i uczyć się dla siebie. Jeśli ten wstępny warunek jest spełniony, wówczas możliwe jest spełnienie następnych aspektów modelu PCA.

2. Nauczyciel dzieli się z uczniami, studentami, rodzicami bądź władzami szkolnymi odpowiedzialnością za proces uczenia się.

3. Nauczyciel dostarcza materiałów do uczenia się, korzystając z własnej wiedzy i doświadczenia, a także z materiałów źródłowych lub doświadczeń społecznych.

4. Uczeń sam lub we współpracy z innymi konstruuje i rozwija swój własny program uczenia się. Dokonuje wyboru kierunku własnej nauki z pełną świadomością ponoszenia odpowiedzialności i konsekwencji tego wyboru.

5. W klasie tworzy się stopniowo klimat ułatwiający uczenie się. Początkowo jest on kreowany przez nauczyciela, jednak w miarę kontynuowania procesu uczenia się coraz częściej wytwarzają go dla siebie sami uczniowie. Uczenie się od siebie nawzajem staje się tak ważne, jak uczenie się z książek, filmów i z doświadczeń w pracy.

6. Wszystko ogniskuje się wokół utrzymania stałego procesu uczenia się. Treść uczenia się, chociaż ważna, schodzi na drugi plan. Efekty mierzy się tym, czy uczeń zrobił wyraźny postęp w uczeniu się.

7. Samodyscyplina zastępuje zewnętrzną dyscyplinę.

8. Ocena efektów pracy ucznia jest dokonywana przez niego samego oraz jest wzbogacana informacjami zwrotnymi ze strony innych członków grupy i nauczyciela.

9. W takim klimacie wspomagającym rozwój, uczenie się ma tendencje do pogłębiania się, zwiększania tempa i większego przenikania się z życiem i zachowaniem ucznia, niż ma to miejsce w uczeniu się w tradycyjnej klasie, szkole. Dzieje się tak dlatego, że kierunek uczenia się jest własnym 
wyborem, uczenie się stanowi własną inicjatywę, a w proces uczenia się jest zaangażowana cała osoba z uczuciami, namiętnościami i intelektem.

Nauczyciel pracujący zgodnie z powyższym modelem koncentruje się na tym, aby uczeń mógł poczuć się w szkole bezpiecznie, by dążył do samorealizacji. Pomaga wychowankowi w osiągnięciu umiejętności samodzielnego podejmowania działań i ponoszenia pełnej odpowiedzialności za ich skutki, inteligentnego wyboru celu działania i takiego kierowania swoją aktywnością, aby cel ten mógł być osiągnięty. Uczeń może wykorzystywać w sposób twórczy dotychczasowe doświadczenia i współdziałać z innymi ludźmi dla realizowania społecznie akceptowanych celów (Iłendo-Milewska, 2007).

\section{Zakończenie}

Szkoła, obok domu rodzinnego i grupy rówieśniczej, to jedno z najsilniej oddziałujących na rozwój adolescenta środowisk wychowawczych. Sprzyja zaspokajaniu ważnych potrzeb emocjonalno-społecznych, stwarza możliwość angażowania się w działania prospołeczne, wyznacza klarowne zasady, sprzyja tworzeniu pozytywnego klimatu.

W szkole powinien być stworzony bezpieczny świat dla każdego przez podjęcie takich działań jak: wprowadzenie spójnego, jasnego i zrozumiałego systemu zasad i praw szkolnych, które nie tylko są zapisane, ale są też przestrzegane i realizowane przez wszystkich uczestników szkolnego życia, upowszechnianie hierarchii wartości i systemu wzorców, którymi należy się w szkolnym życiu kierować. Także nauczyciele powinni mówić i dyskutować o problemach i zagrożeniach, ale też nie zapominać o szansach i możliwościach, jakie niesie ze sobą dzisiejszy szkolny świat. Chodzi bowiem nie tyle o budzenie lęku, ile uświadomienie i zrozumienie zagrożeń oraz pokazanie innych dróg i sposobów na życie (Sałasiński, Wandziukiewicz, 2003).

Zadaniem nauczycieli jest monitorowanie, diagnozowanie i podejmowanie działań mających na celu rozwiązywanie problemów bezpieczeństwa młodzieży. Przez zgodne oddziaływania wszystkich nauczycieli można uzyskać zmianę w zachowaniach uczniów zagrożonych nieprzystosowaniem społecznym. Chcąc stymulować rozwój społeczny, należy uczniom stawiać zadania ukierunkowane na wzmacnianie pozytywnych przejawów zachowania, wspierać ich w tym, co dobre, wydobywać z nich to, co najpiękniejsze i najcenniejsze (Kosińska, 2002). Aby uczeń mógł prawidłowo rozwijać się, musi mieć zapewnione poczucie bezpieczeństwa w szkole, i nie chodzi wyłącznie o bezpieczeństwo fizyczne, ale również o poczucie bezpieczeństwa wewnętrznego - odrobi- 
ny zrozumienia, akceptacji, empatii ze strony człowieka dorosłego. To ważne zadanie stojące przed każdą szkołą, która pragnie być bezpieczna i przyjazna uczniom.

\section{Bibliografia}

Brammer L. M. (1984), Kontakty stużące pomaganiu, PTP, Warszawa.

Danilewska J. (2002), Agresja u dzieci-szkoła porozumienia, WSiP, Warszawa.

Dotka M. (2010). Klimat społeczny jako czynnik wptywajacy na specyfikę szkoty, http://www. cmppp.edu.pl/node/19866 (dostęp: 10.09.2010).

Dróżdż K. (2001), Edukacja w perspektywie integracji europejskiej w: Ochmański M., Sokołowiej-Dzioba T., Pielecki A. (red.), Edukacja w perspektywie integracji Europy, WSP TWP, Warszawa.

Gaś Z. B. (red.) (2004), Badanie zapotrzebowania na profilaktykę w szkole. Poradnik dla szkolnych liderów profilaktyki, Masz Szansę, Lublin, s. 17.

Grodowska M., Kowalska M. (2003), Wychowawczy program profilaktyczny, Rubikon, Kraków.

Gryniuk I., Tuszyńska-Bogucka V. (2004), Psychorysunek tematyczny jako narzędzie diagnozy sytuacji szkolnej i rodzinnej ucznia, w: Gaś Z. B. (red.), Badanie zapotrzebowania na profilaktykę w szkole Poradnik dla szkolnych liderów profilaktyki, Masz Szansę, Lublin.

Hall C. S., Lindzey G. (2002), Teorie osobowości, PWN Warszawa

Iłendo-Milewska A. (2007), Dysfunkcjonalność uczniów gimnazjum, Difin, Warszawa.

Kiełczewska A. K. (2010), Jak zwiększyć bezpieczeństwo uczniów w szkole, www.raabe.pl/e-letter/szkoly/nr8-08-2009/podstrona5.htm (dostęp: 13.09.2010).

Klus-Stańska D., Nowicka M. (1999), Bezpieczeństwo dzieci. Scenariusze dla rodziców i nauczycieli, „Impuls”, Kraków, s. 6.

Kosińska E. (2002), Mądrze i skutecznie. Zasady konstruowania szkolnego programu profilaktyki, Rubikon, Kraków, s. 6.

Kwieciński Z. (1992), Socjopatologia edukacji, IRWiR PAN, Warszawa.

Latecki M., Krakowska B. (2010), Zjawisko agresji wśród gimnazjalistów a bezpieczeństwo osób przebywajacych na terenie szkoty, w: Majchrzak N., Zduniak A. (red.), Jakość wobec wyzwań i zagrożeń XXI wieku, Wyd. Wyższej Szkoły Bezpieczeństwa, Poznań, s. 207.

Łobocki M., (1994), Psychologia humanistyczna a wychowanie, UMCS, Lublin. 


\section{ORYGINALNE ARTYKUŁY BADAWCZE}

Mantur J. (2012) (red.), Styl życia młodzieży Białegostoku, CKU, Białystok.

Markocki Z. (2009), Edukacja w dobie globalnego społeczeństwa informacyjnego, w: Czajkowska A., Otwinowski W. (red.), Edukacyjne zagrożenia $i$ wyzwania młodego pokolenia, Wyd. Wyższej Szkoły Bezpieczeństwa, Poznań, s. 171.

Maslow A. H. (1986), W strone psychologii istnienia, IW PAX, Warszawa.

Maslow A. H. (1990), Motywacja i osobowość, IW PAX, Warszawa.

Moos R. H. (1979), Evaluating educational environments: Procedures, measures, findings and Policy implications, San Francisco, s. 89-96.

Mydlak Z. (1993), Funkcjonowanie młodych nauczycieli w sytuacjach szkolnych, Wyższa Szkoła Pedagogiczna im. Powstańców Śląskich w Opolu, Opole.

Nowak S. (1988), Dylematy i antynomie świadomości społecznej drugiej polowy lat osiemdziesiatych, „Nowiny Psychologiczne”, vol. 4.

Porzak R. (1994), Wychowanie jako proces tworzenia warunków do rozwoju, w: Gaś Z. B. (red), Wspomaganie rozwoju dziecka, Masz Szansę, Lublin.

Rogers C. R. (1983), Freedom to learn for the 80's, Columbus OH Merrill, Ohio.

Rogers C. (1991), Terapia nastawiona na klienta. Grupy spotkaniowe, Thesaurus-press, Wrocław.

Sałasiński M., Badziukiewicz B. (2003), Vademecum pedagoga szkolnego, WSiP, Warszawa.

Sitarczyk M. (1999), Nauczyciel w percepcji uczniów o zróżnicowanym poziomie osiagnięć szkolnych. Zasady percepcji interpersonalnej z uwzględnieni relacji uczeń - nauczyciel, w: Gaś Z. B. (red.), Szkoła i nauczyciel w percepcji uczniów, Instytut Badań Edukacyjnych, Warszawa, s. 115-127.

Świątkiewicz G. (red.) (2002), Profilaktyka w środowisku lokalnym, Krajowe Biuro ds. Przeciwdziałania Narkomanii, Warszawa, s. 49-51.

Taraszkiewicz M., Kordziński J. (2009), Bezpieczna i przyjazna szkoła, WSiP, Warszawa.

Tchorzewski M. (red.) (1994), Rola wartości i powinności moralnych w kształtowaniu świadomości profesjonalnej nauczycieli, Wyższa Szkoła Pedagogiczna, Bydgoszcz.

Tokarczyk E. (1996), Nieprzystosowanie społeczne, demoralizacja i przestępczość dzieci i młodzieży, w: K. Ostrowska, J. Tatarowicz (red.), Zanim w szkole będzie źle, Centrum Metodyczne Pomocy Psychologiczno-Pedagogicznej, Warszawa, s. 128.

Więckowski R. (1995), Społeczny klimat klasy szkolnej a rozwój twórczej aktywności, „Życie Szkoły", nr 5, s. 261.

Zemło M. (2012), Środowisko szkolne w opinii uczniów szkół białostockich, w: Mantur J. (red.), Styl życia młodzieży Białegostoku, CKU, Białystok, s. 31, 37. 


\section{Quality of functioning of student's in scholastic environment. The analysis of safety confidence in perception of students of various school types}

\section{Summary}

This chapter is dedicated to subject area of quality of functioning of student's in scholastic environment, with emphasis on safety confidence in students perception. Theoretical basis refers to humanistic psychology, theory of C. Rogers (1983) and PCA (Person Centered Approach) model. Quoted research were meant to recognize the opinion of students on the subject of safety in schools, diagnosing the situation in schools and carrying out actions which would increase safety in scholastic environment.

Keywords: scholastic environment, safety confidence, dysfunctional behaviors, student. 